\title{
Burn Pits, Iraq Afghanistan War Lung Injury (IAW-LI), and the Specter of Agent Orange De Ja Vu
}

\author{
Anthony M Szema* \\ Faculty, Internal Medicine Residency Program at Mather Hospital, Northwell Health, USA
}

Received: June 04, 2018; Published: June 11, 2018

*Corresponding author: Anthony M Szema, Faculty, Internal Medicine Residency Program at Mather Hospital, Northwell Health, USA

\section{Opinion}

This past Memorial Day honored our brave patriots who have lost their lives in the Iraq and Afghanistan War, but today we must not forget the noble obligation to help those still suffering. The wars in Iraq Afghanistan have been unprecedented because women and men have been exposed to novel airborne hazards such as:

a) Burning trash "in burn pits";

b) Vehicle Improvised Explosive Devices (VID);

c) Dust storms;

d) Shock waves from exploding bombs. Soldiers with new onset respiratory symptoms from these hazards post deployment are being diagnosed with Iraq Afghanistan War Lung Injury GAW-LI).

IAW-LI is hazardous for soldiers' health; this war-induced disease impacts multiple dimensions of everyday life, such as the ability to perform one's job and the ability to exercise. We have conducted research on this disease and discovered soldiers suffering from this war-related lung injury have new onset asthma or fixed obstructed airways. We have reported titanium that is bound to iron in fixed mathematical ratios of $1: 7$, which is extremely rare in nature, in the lungs of soldiers. This suggests an anthropogenic, man-made source. In more severe cases, these soldiers became respiratory cripples that required a lung transplant. IAW-LI is a long-term disease that does not disappear years later, even though some of these soldiers were exposed in 2003. Symptoms as severe as these are not detectable by routine testing and require sophisticated quaternary care.

Currently, there is no treatment available for this disease process, but we are investigating several candidate medications in development which we have seen to reverse IAW-LI injuries in mice. While this problem requires a bipartisan solution, we urge the current Trump Administration to foster interdisciplinary collegiate collaborations to expedite novel therapies for our soldiers. It is important that independent, academic medical centers, such as: the International Center of Excellence in Deployment Health and Medical Geosciences, Northwell Health; Vanderbilt; and National Jewish Deployment Center, receive funding for this emerging, critically-important disease. Because of the VA's dereliction of duty to this matter for the last fifteen years; it is our generation's Agent Orange. These independent academic medical centers can report annually to Congress, analogous to World Trade Center monitoring programs. The World Trade Center Monitoring Programs have provided care and research to improve health and quality of life of those affected by airborne bioterrorism attacks at Ground Zero.

IAW-LI sometimes is not easily diagnosed by physicians, because many are still unaware of this injury. Also, it is difficult for suffering patients to realize what their symptoms are because this is an unconventional disease. Many believe the symptoms are attributed to Post Traumatic Stress Disorder, not IAW-LI. Sophisticated tests as impulse oscillometry and analysis of lung tissue for metals are only available at Quaternary Care Medical Centers.

On Memorial Day we honored all the men and women who sacrificed their lives for our country. As fellow citizens, it is our patriotic duty to raise awareness of this potentially-life altering injury. These brave individuals need the public to aid them. We owe our heroes the knowledge, treatment, and care to best help them recover from this injury. The amount of funding is miniscule compared to the sacrifices these extraordinary citizens make daily. On this Memorial Day, please urge the Trump Administration to fund academic research to stop the suffering of these patriots and their families. 
(C) This work is licensed under Creative

Submission Link: https://biomedres.us/submit-manuscript.php

Assets of Publishing with us
RESEARCHES $\quad \begin{aligned} & \text { Global archiving of articles } \\ & \text { - Immediate, unrestricted online access } \\ & \text { - Rigorous Peer Review Process }\end{aligned}$

